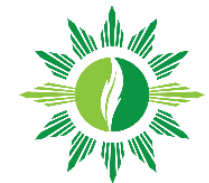

\title{
Pengaruh Jenis Pakan dan Perbedaan Kelamin Terhadap Pertumbuhan dan Periode Molting Kepiting Bakau (Scylla Serrata)
}

\author{
Ismail Failu ${ }^{1^{*}}$ \\ ${ }^{1}$ Fakultas Pertanian, Universitas Muhammadiyah Buton, Indonesia \\ *Korespondensi: ismailfailu56@gmail.com
}

\begin{tabular}{c}
\hline Info Artikel \\
\hline Diterima 25 Juli \\
2021 \\
Disetujui 23 \\
Agustus 2021 \\
Dipublikasikan 31 \\
Agustus 2021 \\
Keywords: \\
Pakan, Jenis \\
Kelamin, \\
Pertumbuhan, \\
Molting \\
\hline
\end{tabular}

(C) 2021 The Author(s): This is an open-access article distributed under the terms of

the Creative

Commons

Attribution

ShareAlike (CC BY-

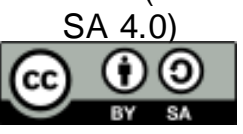

\section{Abstrak}

Tujuan yang ingin dicapai dalam penelitian ini adalah untuk mengetahui pakan yang berbeda terhadap pertumbuhan dan periode molting kepiting bakau (S. serrata) jantan dan betina. Sedangkan kegunaan dari hasil penelitian ini di harapkan dapat menjadi bahan informasi bagi pembudidaya kepiting bakau (Scylla Serrata) terutama dalam hal aplikasi pakan uji. Penelitian ini dilaksanakan mulai Oktober - Desember 2020 di perairan Desa Boneatiro Kecamatan Kapontori Kabupaten Buton. Rancangan percobaan adalah rancangan acak kelompok pola faktorial. Faktor pertama adalah jenis kelamin kepiting yang terdiri dari dua taraf yaitu jantan (A1) dan betina (A2). Faktor kedua terdiri dari 3 taraf yaitu perlakuan pakan B1 (ikan teri), pakan B2 (usus ayam), dan pakan B3 (cumi-cumi) dengan dosis pakan 5\% dari bobot tubuh kepiting bakau. Kombinasi seluruh perlakuan berjumlah enam (6) dan masing-masing perlakuan di ulang tiga (3) kali sehingga diperoleh satuan percobaan sebanyak 18 unit percobaan. Variable yang diamati meliputi panjang dan lebar karapas, bobot tubuh, kelangsungan hidup, dan periode molting. Pemberian berupa pakan usus ayam pada kepiting bakau jenis kelamin jantan dan betina memberikan pertumbuhan mutlak (h) dan pertumbuhan harian (SGR) tertinggi serta, tingkat kelangsungan hidup (SR) terbesar diperoleh dari pemberian pakan usus ayam. Sedangkan periode molting tercepat berlangsung 14 hari pada pemberian pakan usus ayam dan terjadi pada jenis kelamin jantan.

\section{Abstract}

The aim of this study was to determine the different feeds on the growth and molting period of male and female mangrove crabs (S. serrata). While the usefulness of the results of this study is expected to be information material for mud crab (Scylla Serrata) cultivators, especially in terms of test feed applications. This research was carried out from October to December 2020 in the waters of Boneatiro Village, Kapontori District, Buton Regency. The experimental design was a factorial randomized block design. The first factor is the sex of the crab which consists of two levels, namely male (A1) and female (A2). The second factor consisted of 3 levels, namely the treatment of $B 1$ feed (anchovies), B2 feed (chicken intestines), and B3 feed (squid) with a feed dose of $5 \%$ of body weight of mud crabs. The combination of all treatments was six (6) and each treatment was repeated three (3) times so that 18 experimental units were obtained. The observed variables included carapace length and width, 
body weight, survival, and molting period. Provision of chicken intestine feed to male and female mangrove crabs gave the highest absolute growth (h) and daily growth (SGR) and the greatest survival rate (SR) was obtained from chicken intestine feeding. While the fastest molting period lasts 14 days on chicken intestine feeding and occurs in the male sex.

\section{Pendahuluan}

Kepiting bakau (Scylla serrata) merupakan salah satu sumberdaya hayati perairan yang memiliki nilai ekonomis tinggi baik pasar impor maupun ekspor. Permintaan ekspor di Negara luar antara lain Asia seperti Singapura, Thailand, Taiwan, Hongkong dan China, maupun di Amerika dan Eropa (Tulangow et al., 2019). Dalam perdagangan internasional jenis kepiting bakau dikenal sebagai Mud Crab atau bahasa Latinnya Scylla spp.

Meningkatnya permintaan konsumen terhadap kepiting bakau, khu susnya di pasar internasional, berdampak pada upaya budidaya kepiting bakau melalui budidaya yang intensif. Para petambak tertarik membudidayakan kepiting bakau karena potensi ekonomi yang tinggi dari kepiting bakau tersebut.

Penerapan pakan bernutrisi dan perbaikan sistem budidaya merupakan dua faktor penentu keberhasilan budidaya kepiting bakau. untuk membudidayakan kepiting yang berkembang dengan cepat dan memiliki tingkat kelangsungan hidup yang tinggi. Kepiting bakau seperti hewan air lainnya, hanya bisa berkembang jika ada kelebihan energi. Setelah energi yang dikeluarkan berkurang oleh kebu tuhan energi untuk berbagai aktivitas, pertumbuhan kepiting akan meningkat.

Setiap perubahan lingkungan akan mengubah jumlah energi yang dikonsumsi, yang dapat menjadi lebih besar atau lebih kecil daripada jumlah energi yang dimetabolisme yang mengakibatkan peningkatan atau pengurangan energi tubuh.

Sara et al. (2017) menyatakan bahwa karakteristik kepiting tidak memilihmilih makanan, misalnya kulit kodok, isi perut hewan, bangkai binatang, siput, ikan racun, jenis kerang-kerangan, dan sisa-sisa makanan.

Dalam usaha budidaya, makanan yang mudah bagi kepiting adalah cincangan ikan rucah baik segar maupun diawetkan. Pemberian pakan rutin dengan dosis yang tepat sangat penting untuk pemeliharaan penggemukan kepiting. Karena kepiting lebih aktif mencari makan di malam hari, maka dosis makan pagi lebih rendah dibandingkan dengan dosis makan sore (nokturnal).

Oleh karena itu, penelitian tentang pengaruh jenis pakan dan perbedaan jenis kelamin terhadap pertumbuhan dan waktu molting kepiting bakau (Scylla serrata) akan sangat bermanfaat dalam memajukan budidayanya.

\section{Metode Penelitian}

\subsection{Waktu dan Tempat}

Penelitian berlangsung di perairan Desa Boneatiro, Kecamatan Kapontori, Kabupaten Buton, pada bulan Oktober hingga Desember 2020. 


\subsection{Alat dan Bahan}

Alat yang digunakan: Jangka sorong (Mengukur panjang dan lebar karapas), Timbangan duduk (Mengukur bobot kepiting bakau) sedangkan bahan yang digunakan : Kurungan bamboo (Wadah pemeliharaan kepiting bakau), Kepiting bakau (Hewan uji), Pakan uji (Ikan Rucah, Usus Ayam, Cumi-Cumi)

Wadah yang digunakan dalam penelitian ini adalah petak kurungan yang terbuat dari bambu. Kurungan terdiri dari 2 unit. Setiap unit terdiri dari 9 petakan, dimana setiap petakan berukuran $50 \mathrm{~cm} \times 50 \mathrm{~cm} \times 50 \mathrm{~cm}$ (gambar 3).

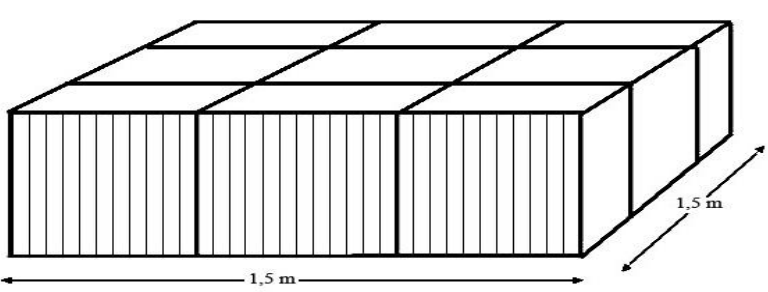

Gambar 1. Rancangan Petak Kurungan yang Digunakan Dalam penelitian

\subsection{Rancangan Percobaan}

Rancangan percobaan adalah rancangan acak kelompok pola faktorial. Faktor pertama adalah jenis kelamin kepiting yang terdiri dari dua taraf yaitu jantan (A1) dan betina (A2). Faktor kedua terdiri dari 3 taraf yaitu perlakuan pakan B1 (ikan teri), pakan B2 (usus ayam), dan pakan B3 (cumi-cumi) dengan dosis pakan $5 \%$ dari bobot tubuh kepiting bakau. Kombinasi seluruh perlakuan berjumlah enam (6) dan masing - masing perlakuan di ulang tiga (3) kali sehingga diperoleh satuan percobaan sebanyak 18 unit percobaan.

\subsection{Sumber Benih dan Aklimatisasi}

Kepiting bakau yang menjadi obyek penelitian diperoleh dari Teluk Lawele yang di tangkap dengan bubu. Kepiting bakau menjadi hewan uji tersebut kemudian diidentifikasi jenis kelaminnya, diukur bobot, panjang dan lebar karapasnya.

Semua kepiting bakau yang di peroleh tersebut terlebih dahulu di aklimatisasi dengan kondisi setempat sebelum penelitian aktual di laksanaka.

Setelah melewati proses aklimatisasi, maka setiap individu kepiting bakau langsung ditempatkan pada kurungan yang telah tersedia dengan jumlah satu (1) individu (ekor) perpetak kurungan pemeliharaan. Sebelumnya setiap kurungan telah diberi tanda (kode) berdasarkan kelompok, perlakuan dan ulangan.

\subsection{Pemberian Pakan}

Hewan uji diberi pakan berupa potongan-potongan ikan rucah (jenis ikan teri), usus ayam dan cumi-cumi dengan dosis pakan $5 \%$ dari bobot tubuhnya seban yak satu kali yaitu pada pukul 16.00 - 17.00 sore. Pemberian makan sore dikaitkan dengan sifatkepiting bakau yang sibuk mencari makan di malam hari (nokturnal).

\subsection{Pengukuran Kualitas Air}

Parameter kualitas air diukur pada saat pasang dan surut. Parameter kualitas air yang diukur terdiri dari salinitas, suhu, DO, pH. 


\subsection{Variable Yang Diamati}

Variable yang diamati meliputi panjang dan lebar karapas, bobot tubuh, kelangsungan hidup, dan periode molting.

\subsection{Analisis Data}

Untuk menentukan pertumbuhan bobot tubuh, panjang dan lebar karapas hewan uji dihitung dengan rumus :

a) Pertumbuhan berat mutlak individu rata-rata akan dihitung dengan berpedoman pada rumus yang dikemukakan Sukarya (1991) sebagai berikut:

$$
\mathbf{W M}=\mathbf{W t}-\mathbf{W o}
$$

keterangan :

WM : pertumbuhan mutlak hewan uji (g)

Wt : Bobot rata - rata pada akhir penelitian (g)

Wo : Bobot rata - rata pada awal penelitian (g)

Sebaliknya, pertumbuhan mutlak berdasarkan panjang dan lebar karapas

$$
: \mathbf{L m}=\mathbf{L t}-\mathbf{L o}
$$

Keterangan :

Lm : panjang/lebar karapas mutlak individu $(\mathrm{mm})$

Lt : panjang/lebar karapas individu pada akhir penelitian ( $\mathrm{mm})$

Lo : panjang/lebar karapas mutlak individu awal penelitian (mm)

b) Changbo et al. 2004 menghitung tingkat pertumbuhan berat badan spesifik harian (Wahidin et al., 2016).

$$
S G R=\frac{(\ln W t-\ln W o)}{t} X 100
$$

Keterangan :

SGR : Laju Pertumbuhan Bobot Spesifik Harian (\%),

(g),

Wo : Bobot Rata-Rata Kepiting Bakau Pada Awal Penelitian

Wt : Bobot Rata-Rata Kepiting Bakau Pada Waktu t (g), dan

t : Lama Pemeliharaan (hari).

1. Tingkat kelangsungan hidup (Cruz-Suarez et al., 2007):

$$
S R=\frac{N t}{N o} X 100 \%
$$

keterangan :

SR : Tingkat kelangsungan hidup

$\mathrm{Nt}$ : Jumlah individu akhirpenelitian ( ekor)

No : Jumlah individu awal penelitian (ekor) 
c) Produksi biomassa kepiting diperkirakan untuk setiap perlakuan dengan mengalikan berat rata-rata tiap individu dengan jumlah kepiting yang hidup pada kesimpulan percobaan (Karim, 2002).

$$
\mathbf{P b}=\mathbf{W} \cdot \mathbf{N}
$$

Untuk mengetahui pengaruh jenis pakan dan perbedaan jenis kelamin terhadap pertumbuhan dan periode molting yang diamati, di analisis dengan menggunakan sidik ragam. Jika hasil analisis menunjukan pengaruh nyata, maka dilanjutkan dengan uji beda nyata terkecil (BNT) pada taraf kepercayaan $5 \%$ (Hanafiah, 1995).

\section{Hasil}

\subsection{Pertumbbuhan Mutlak Kepiting Bakau}

Dari hasil pengukuran pertu mbuhan mutlak bobot kepiting bakau dapat telihat pada Gambar 2.

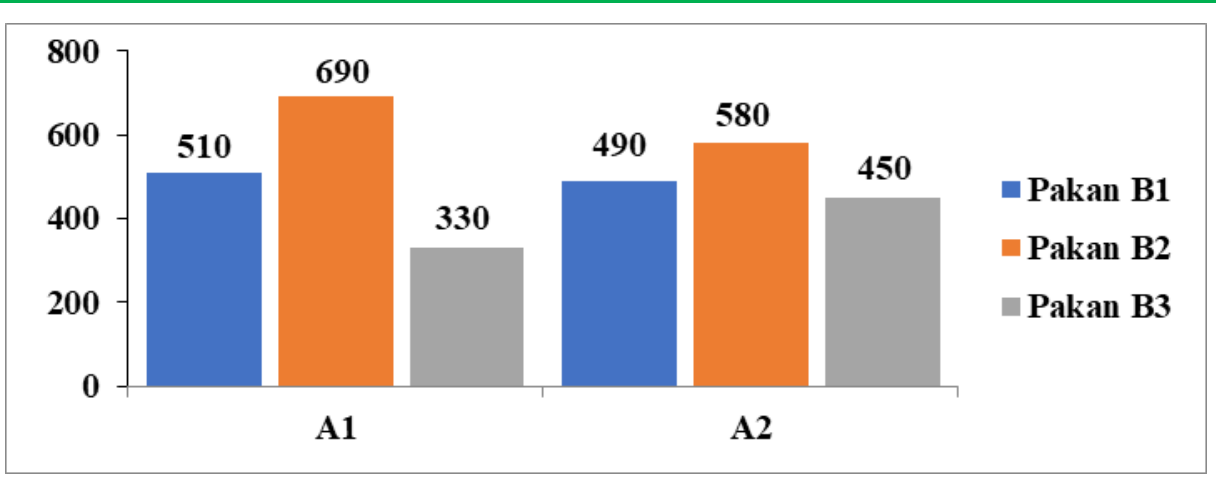

Gambar 2. Grafik Rata-rata Pertumbuhan Mutlak Bobot Tubuh Kepiting Bakau (Scylla Serrata) Pada Setiap Perlakuan Selama Penelitian.

Berdasarkan Gambar 2 menunjukan bahwa pada kepiting bakau jenis kelamin jantan memberikan niai rata-rata laju pertumbuhan mutlak tertinggi perlakuan A1B2 (Pakan Usus Ayam) dengan rata-rata 230 gram, kemudian diikuti perlakuan A1B1 (Pakan Ikan Teri) dan A1B3 (Pakan Cumi-cumi) dengan rata-rata laju pertumbuhan mutlak masing-masing 170 gram dan 110 gram. Fenomena yang sama terjadi pada jenis kelamin betina dengan nilai laju pertumbuhan mutlak ratarata 193 gram pada perlakuan A2B2 (Pakan Usus Ayam) kemudian perlakuan A2B1 (Pakan lkan Teri) dan A2B3 masing-masing dengan rata-rata 163 gram dan 150 gram.

Tabel 1. Hasil Analisa Pertumbuhan mutlak berdasarkan panjang/lebar karapas kepiting bakau selama penelitian

\begin{tabular}{|c|c|c|c|c|c|c|}
\hline \multirow{2}{*}{$\begin{array}{l}\text { Faktor A } \\
\text { (Jenis } \\
\text { Kelamin) }\end{array}$} & \multirow{2}{*}{$\begin{array}{c}\text { Faktor } \\
\text { B } \\
\text { (Pakan) }\end{array}$} & \multicolumn{3}{|c|}{ Kelompok } & \multirow[b]{2}{*}{ TAB } & \multirow{2}{*}{$\begin{array}{l}\text { Rata- } \\
\text { Rata }\end{array}$} \\
\hline & & 1 & 2 & 3 & & \\
\hline \multirow{3}{*}{ A1 } & B1 & 0.8 & 0.8 & 0.9 & 2.5 & $0.83^{\mathrm{cd}}$ \\
\hline & B2 & 1.2 & 1.3 & 1.2 & 3.7 & $1.23^{\mathrm{e}}$ \\
\hline & B3 & 0.7 & 0.7 & 0.7 & 2.1 & $0.7^{\mathrm{a}}$ \\
\hline \multirow{3}{*}{$\mathrm{A} 2$} & B1 & 0.7 & 0.7 & 0.8 & 2.2 & $0.73^{a b}$ \\
\hline & B2 & 1.1 & 1 & 0.9 & 3.0 & $1^{b c}$ \\
\hline & B3 & 0.8 & 0.8 & 0.8 & 2.4 & $0.8^{d}$ \\
\hline
\end{tabular}




\section{TK}

5.30

5.30

5.30

15.90

5.30

Pada tabel 1 menunjukan bahwa pertumbuhan mutlak kepiting bakau yang dihitung berdasarkan panjang dan lebar karapas kepiting jantan memberikan nilai rata-rata tertinggi pada perlakuan A1B2 (Pakan UsusAyam) yakni sebesar 1.23 gram, kemudian perlakuan A1B1 (pakan Ikan Teri) dan A1B3 masing-masing dengan rata-rata 0.83 gram dan 0.70 gram, begitu pula pada kepiting betina memberikan nilai rata-rata pertumbuhan mutlak pada perlakuan A2B2 (Pakan Usus Ayam) yakni 1 gram dan disusul perlakuan A2B3 sebesar 0.80 gram serta Perlakuan A2B1 yakni sebesar 0.73 gram.

\subsection{Laju Pertumbuhan Harian (SGR) Kepiting Bakau}

Data hasil pengukuran laju pertumbuhan harian kepiting bakau di sajikan dalam Gambar 3.

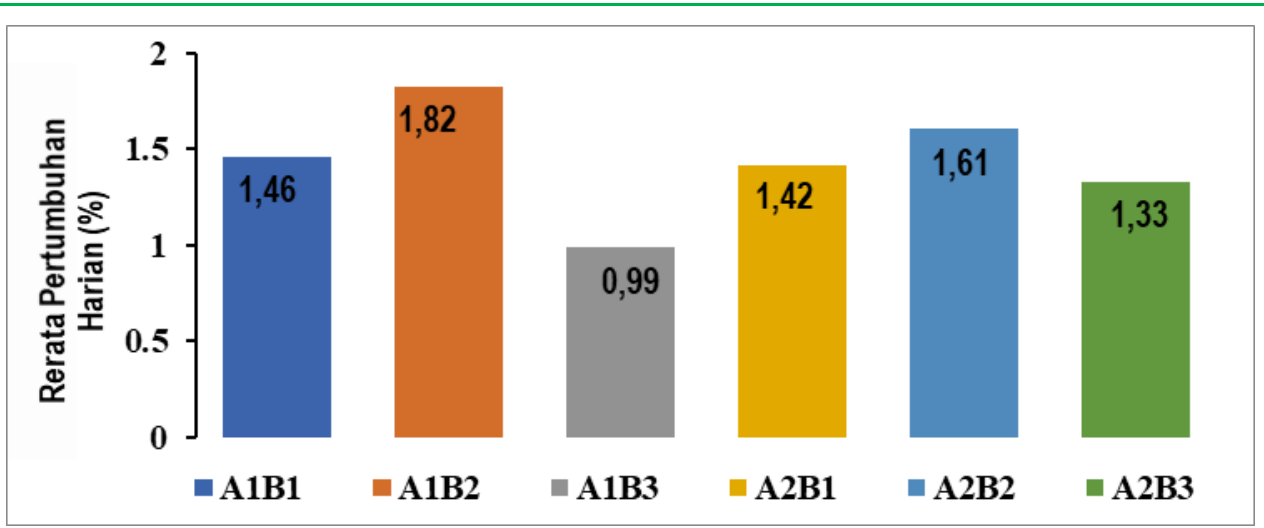

Gambar 3. Histogram Rata-rata Laju Pertumbuhan Harian (SGR) (\%) Kepiting Bakau (Scylla Serrata) Pada Setiap Perlakuan Selama Penelitian.

Berdasarkan Gambar 3 menunjukkan bahwa pada kepiting bakau jenis kelamin jantan memberikan nilai laju pertumbuhan harian (SGR) tertinggi perlakuan A1B2 (pakan usus ayam) dengan rata-rata $1.822 \%$, kemudian diikuti perlakuan A1B (pakan ikan teri) dan A1B3 (pakan cumi-cumi) dengan (SGR) ratarata masing-masing $1.464 \%$ dan $0.991 \%$. Fenomena yang sama terjadi pada jenis kelamin betina dengan nilai laju pertumbuhan harian (SGR) rata-rata $1.610 \%$ pada perlakuan A2B2 (pakan usus ayam) kemudian perlakuan A2B1 (pakan ikan teri) dan A2B3 masing-masing dengan rata-rata $1.421 \%$ dan $1.332 \%$.

\subsection{Tingkat Kelangsungan Hidup (SR) Kepiting Baku}

Data hasil pengukuran tingkat kelangsungan hidup kepiting bakau di sajikan dalam Gambar 4.

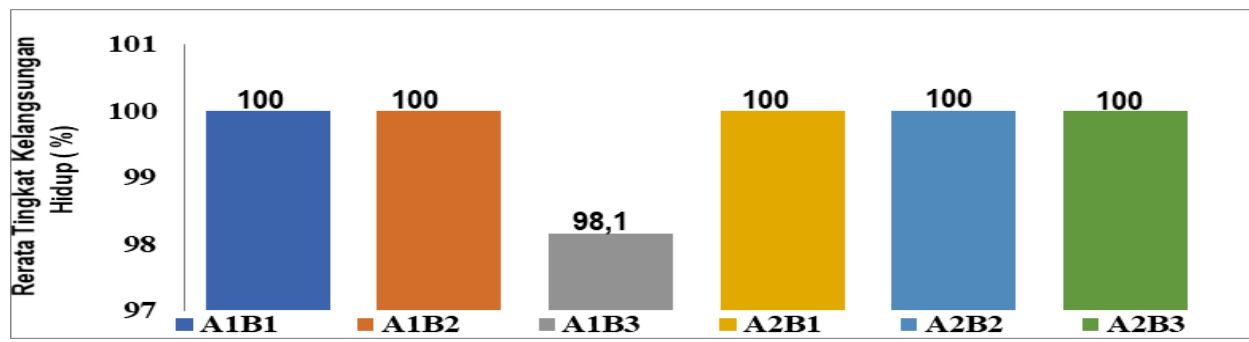

Gambar 4. Histogram Rata-Rata Tingkat Kelangsungan Hidup Kepiting Bakau

(Scylla Serrata) Pada Setiap Perlakuan Selama Penelitian 
Adanya hewan uji (kepiting bakau) yang mati pada jenis kelamin jantan disebabkan oleh karena kepiting bakau tersebut mengalami gagal molting. Gagal molting ini terjadi karena kepiting bakau tersebut tidak dapat meloloskan diri dari kerapas lama. Molting sangat di pengaruhi oleh dua faktor, yakni (1) faktor intrinsik (dalam), yaitu kematangan telur,regenerasi dan perbaikan kaki dan capit yang hilang atau rusak, dan (2) factor ekstrinsik (luar), yaitu temperatur, ketersediaan pakan "overcrowding".

\subsection{Periode Molting Kepiting Bakau}

Periode molting kepiting bakau yang dipelihara selama penelitian disajikan dalam Tabel 2.

Tabel 2. Periode Molting Kepiting Bakau (S. serrata) dalam waktu Pemeliharaan 50 Hari

\begin{tabular}{|c|c|c|c|}
\hline \multicolumn{2}{|c|}{ Perlakuan/Kelompok } & \multirow{2}{*}{$\begin{array}{c}\text { Periode Molting } \\
\text { (Hari) }\end{array}$} & \multirow{2}{*}{$\begin{array}{c}\text { Keterangan } \\
\text { Molting }\end{array}$} \\
\hline \multirow{3}{*}{$\mathrm{A} 1 \mathrm{~B} 1$} & I & & \\
\hline & II & 45 & Tidak Molting \\
\hline & III & 28 & Molting \\
\hline \multirow{3}{*}{ A1B2 } & I & 14 & Molting \\
\hline & II & 14 & Molting \\
\hline & III & 14 & Molting \\
\hline \multirow{3}{*}{ A1B3 } & 1 & 45 & Tidak Molting \\
\hline & II & 45 & Tidak Molting \\
\hline & III & 45 & Mati \\
\hline \multirow{3}{*}{ A2B1 } & I & 45 & Tidak Molting \\
\hline & II & 45 & Tidak Molting \\
\hline & III & 14 & Molting \\
\hline \multirow{3}{*}{ A2B2 } & I & 28 & Molting \\
\hline & II & 21 & Molting \\
\hline & III & 28 & Molting \\
\hline \multirow{3}{*}{ A2B3 } & I & 45 & Tidak Molting \\
\hline & II & 45 & Tidak Molting \\
\hline & III & 45 & Tidak Molting \\
\hline
\end{tabular}

Kepiting bakau yang diberi pakan akan akan memeperlihatkan reaksi dengan mengangkat kedua capitnya dan menggeser posisisnya. Setelah pakan berada dalam genggaman capitnya maka pakan akan segera dibawah kearah mulutnya dan mulai memakannya. Pada umumnya tingkah laku kepiting bakau dalam wadah pemeliharaan pada siang hari selalu berdiam diri dan membenamkan diri dalam lumpur.

Sebelum kepiting mengalami ganti kulit (molting), kepiting bakau tersebut mulai memperlihatkan beberapa ciri pra-molting. Ciri-ciri tersebut antara lain adalah :

a) Aktivitas makan menurun dan selalu membenamkan diri dalam lumpur.

b) Bila ada gangguan, maka kepiting bakau akan segera mengangkat capitnya dan berpindah tempat dengan maksud menyerang. 
c) Bila ada salah satu anggota tubuh (misalnya kaki renang, kaki jalan atau capit) yang hilang, maka pada tempat yang hilang tadi akan tumbuh calon organ pengganti yang lunak.

d) Pada bagian abdomen akan terlihat kemerahan. Hal yang sama juga terlihat pada bagian kaki jalan, kaki renang serta pada ujung capit.

e) Gigi pada capit terlihat tumpul.

\subsection{Kualitas Air}

Table 3. Data kualitas air selama penelitian

\begin{tabular}{cccc}
\hline $\begin{array}{c}\text { Minggu } \\
\text { Pengamatan }\end{array}$ & $\begin{array}{c}\text { Parameter Kualitas } \\
\text { Air }\end{array}$ & Kisaran & Satuan \\
\hline \multirow{3}{*}{ I } & Suhu & $27-30$ & ${ }^{\circ} \mathrm{C}$ \\
\cline { 2 - 4 } & $\mathrm{pH}$ & $7,63-6,89$ & \\
\cline { 2 - 4 } & $\mathrm{DO}$ & $6,2-2,8$ & $\mathrm{ppm}$ \\
\cline { 2 - 4 } IV & Salinitas & $25-32$ & $\mathrm{ppt}$ \\
\cline { 2 - 4 } & Suhu & $29-33$ & ${ }^{\circ} \mathrm{C}$ \\
\cline { 2 - 4 } & $\mathrm{pH}$ & $7,1-8,3$ & \\
\cline { 2 - 4 } & $\mathrm{DO}$ & $5,5-6,0$ & $\mathrm{ppm}$ \\
\cline { 2 - 4 } VII & Salinitas & $29-32$ & $\mathrm{ppt}$ \\
\cline { 2 - 4 } & Suhu & $29-31$ & ${ }^{\circ} \mathrm{C}$ \\
\cline { 2 - 4 } & $\mathrm{pH}$ & $7,3-6,24$ & \\
\cline { 2 - 4 } & $\mathrm{DO}$ & $6,0-2,8$ & $\mathrm{ppm}$ \\
\hline
\end{tabular}

Parameter kualitas air yang diukur selama penelitian (Tabel 3) meliputi DO, $\mathrm{pH}$, suhu, salinitas. Selam penelitian pengukuran parameter kualitas air ini dilakukan tiga kali yakni pada awal penelitian, pertengahan dan akhir penelitian yang masing-masing dilakukan pengukuran pada saat air pasang dan air surut.

\section{Pembahasan}

\subsection{Pertumbuhan}

Berdasarkan hasil penelitian pengaruh jenis pakan dan perbedaan kelamin terhadap pertumbuhan periode molting kepiting bakau (Scylla serrata Forskal) yang dipelihara dalam kurungan bambu menunjukan bahwa nilai pertumbuhan bobot mutlak berbeda tiap perlakuan dimana perlakuan B2 (230 gram) kemudian di ikuti perlakuan B1 (170 gram) dan B3 (110 gram). Hal ini disebabkan oleh kualitas pakan yang diberikan. Akbar et al. (2016) Kualitas pakan pun harus menjadi prioritas, sebab sifat kepiting tidak menyukai pakan sudah busuk, tetapi pakan yang berbau amis dan merangsang sangat disukai.(Muchlisin et al. (2006) Pakan merupakan faktor utama yang harus dipenuhi dan diperhatikan kualitasn ya dalam budidaya penggemukan kepiting.

Dari rata-rata pertumbuhan mutlak jenis kelamin jantan mempunyai (rata-rata 5,771 gram) lebih tinggi dibandingkan dengan jenis kelamin betina (rata-rata 5.662 gram), yang berarti bahwa kepiting bakau jenis jantan mempunyai proses pertumbuhan lebih cepat dari pada kepiting bakau jenis kelamin betina. Sedangkan jika dilihat rata-rata pertumbuhan mutlak perlakuan pakan, maka yang tertinggi adalah perlakuan pemberian pakan usus ayam. hasil penelitian ini membuktikan bahwa pakan usus ayam memberikan konstribusi pertumbuhan yang 
lebih besar pada kepiting bakau dari pada jenis pakan lainnya. Akbar et al. (2016) bahwa pakan usus ayam memberikan nilai pertumbuhan mutlak dan laju pertumbuhan harian terbesar. Data yang diperoleh pada kelompok jantan lebih memberikan pertumbuhan mutlak tertinggi di bandingkan dengan kelompok betin a pada waktu pemeliharaan yang sama. Effendie (1978) dalam Fujaya,(1988) yang menyatakan bahwa roses pertumbuhan dipengaruhi oleh beberapa faktor yakni keturunan, sex, umur, parasit, penyakit, makanan dan suhu perairan.

Hasil analisis ragam $(\alpha=0,05)$ menunjukan bahwa ketiga jenis perlakuan pakan yang diberikan tersebut memberikan nilai perumbuhan mutlak yang sangat nyata $(p<0,05)$. Sementara antara jenis kelamin jantan dan betina memperlihatkan pertumbuhan mutlak yang berbeda sangat nyata. Berdasarkan uji BNT $(\alpha 0,05)$ pada nilai rata-rata pertumbuhan mutlak nilai rata-rata pertumbuhan mutlak A1B1 (jenis kelamin jantan dengan pakan ikan teri) berbeda sangat nyata dengan A1B2 (jenis kelamin jantan dengan pakan pakan usus ayam) dan A1B3 (jenis kelamin jantan dengan pakan cumi-cumi). Hal yang sama terjadi pada nilai rata-rata pertumbuhan mutlak pada A1B2 dengan A1B3. Fenomena seperti ini terjadi ini terjadi juga pada nilai rata-rata pertumbuhan mutlak yang yang diperoleh dari jenis kelamin betina yang diberikan jenis pakan yang berbeda.

Dari hasil penelitian ini diperoleh bahwa nilai perumbuhan harian (SGR) tertinggi diperoleh pada pemberian pakan usus ayam (B2). Hal ini kemungkinan disebabkan oleh pakan usus ayam lebih disukai dibandingkan jenis pakan lain yang diberikan. Preferensi ini kemungkinan disebabkan oleh aroma usus ayam lebih disukai oleh kepiting bakau. Berdasarkan hal ini maka sumber energi yang terdapat dalam usus ayam langsung digunakan untuk pertumbuhannya.

Hasil yang diperoleh dari penelitian ini didukung oleh (Alam et Safiah 2009). Berdasarkan nilai pertumbuhan yang diberikan lebih tinggi maka Safiah (2009) menyarankan bahwa pakan usus ayam lebih baik digunakan sebagai pemeliharaan atau penggemukan kepiting bakau, karena jenis pakan ini lebih ekonomis dan yang lebih penting dari usus ayam ini adalah mempunyai aroma yang lebih merangsang nafsu makan kepiting bakau dibandingkan dengan ikan teri dan cumi-cumi. Berdasarkan hal ini maka arus dalam petak pemeliharaan kepiting bakau harus diperhatikan, kepiting bakau dalam mencari makanan lebih mengutamakan penciuman (chemorecepchin) dibanding dengan pen glihatannya. Oleh karena itu jika arus kurang maka nafsu makan kepiting bakau juga rendah atau berkurang (Safiah, 2010, komunikasi pribadi).

Hasil analisis ragam (lampiran Tabel...) $(\alpha=5 \%)$ menunjukkan bahwa nilai SGR antara jenis kelamin jantan dan betina yang diberikan pakan yang sama, kenyataan ini menunjukkan bahwa baik kepiting bakau jenis kelamin jantan dan betina memberikan respon yang relatif sama terhadap pemberian pakan yang sama. Nilai SGR antara jenis kelamin jantan dan betina berbeda sangat nyata berdasarkan pemberian pakan yang berbeda. Nilai SGR A1B1 (jenis kelamin jantan dengan pakan ikan teri) berbeda sangat nyata dengan A1B2 (jenis kelamin jantan dengan pakan usus ayam) dan A1B3 (jenis kelamin jantan dengan pakan cumi-cumi). Hal yang sama terjadi pada nilai rata-rata pertumbuhan mutlak pada A1B2 dengan A1B3. Fenomena seperti ini terjadi ini terjadi juga pada nilai rata-rata pertumbuhan mutlak yang yang diperoleh dari jenis kelamin betina yang diberikan jenis pakan yang berbeda 


\subsection{Kelangsungan Hidup}

Dari enam ekor hewan uji (kepiting bakau) yang diberi perlakuan pakan cumi cumi hanya satu yang mati, sementara lima ekor lainnya pada saat akhir penelitian baru siap akan molting. Hal ini diketahui setelah diadakan pemeriksaan pada bagian belakang karapas setiap individu mulai retak. Setelah diadakan penimbangan bobot tubuh maka bobot tubuh mulai bertambah. Kepiting bakau yang diberi perlakuan pakan cumi-cumi satu ekor mati ini terjadi pada jenis kelamin jantan. Kenyataan ini menunjukkan bahwa sumber energi pakan cumi-cumi yang diberikan belum cukup, berarti untuk merangsang pertumbuhannya dalam dalam waktu pemeliharaan yang sama pada pemberian jenis pakan lainnya (Wahidin et al., 2016). Ketersediaan pakan yang cukup dan berkualitas tinggi serta daya dukung lingkungan akan mengefisienkan penggunaan energi sehingga dapat dimanfaatkan oleh organisme untuk mempertahankan kelangsungan hidupnya.

Berdasarkan hasil analisis ragam menunjukkan bahwa tingkat kelangsungan hidup (SR) antar jenis kelamin maupun antar ketiga perlakuan memperlihatkan perbedaan tidak nyata walaupun nilai rata-rata kelangsungan hidup (sintasan) antara jenis kelamin jantan dan jenis kelamin betina menunjukkan nilai yang berbeda. Nilai rata-rata jenis kelamin jantan dan betina dalam penelitian adalah $2,15 \%$ dan $1,96 \%$. Hal yang juga terjadi di antara jenis pakan. Nilai rata-rata kelangsungan hidup tertinggi diperoleh pada perlakuan B2 (pakan usus ayam) yaitu $6,45 \%$ kemudian diikuti dengan perlakuan B1 (ikan teri) yaitu $5,55 \%$ dan B3 (pakan cumi-cumi) yang mempunyai rata-rata yaitu $4,65 \%$.

\subsection{Periode Molting}

Berdasarkan analisis data secara deskriptif menunjukan bahwa dari kesembilan ekor hewan uji kepiting jantan yang mengalami molting sebanyak 5 ekor sedangkan kepiting bakau jenis betina yang mengalami molting sebanyak 4 ekor. Hasil ini sesuai yang didapatkan oleh Syarif (2000) dan pratiwi (2001) bah wa antara kepiting bakau jenis kelamin jantan dan betina yang lebih cepat dan lebih banyak mengalami molting adalah jenis kelamin jantan. Hal ini disebabkan pakan yang diberikan pada kepiting bakau pada jenis kelamin betina selain digunakan untuk pertumbuhan, juga digunakan dalam proses pematangan gonad, sedangkan pada jenis kelamin jantan pakan yang diberikan digunakan untuk pertumbuhan saja, selain itu kepiting bakau jen is kelamin jantan lebih rakus makannya dibanding jenis kelamin betina (Markus, 1987 dalam Hanafi,1992), sehingga pertumbuhan dan periode molting lebih cepat terjadi pada kepiting bakau jenis kelamin jantan. Menurut Hill (1978), ada beberapa faktor yang menyebabkan nafsu makan kepiting bakau menurun yaitu suhu dan pada saat akan ganti kulit (molting).

Sementara kepiting bakau yang baru saja ganti kulit (molting) terlihat berdiam diri dengan kondisi tubuh yang lunak dan belum dapat bergerak. Dengan kondisi yang lunak ini maka kerapas yang bergerak atau berdenyut saat kepiting bernapas terlihat dengan jelas.

Proses pen Ikan Rucah, Usus Ayam, Cumi-Cumi gerasan kulit setelah ganti kulit (molting) relatif sama, baik pada jenis kelamin jantan maupun betina dan antara pemberian jenis pakan, yaitu berlangsung antara 7-8 hari. Proses pengerasan kulit ini dipengaruhi oleh beberapa faktor, antara lain ukuran kepiting bakau dan kondisi lingkungan tempat pemeliharaan. Semakin besar ukuran kepiting bakau akan semakin lama proses pergantian kulitnya, demikian pula 
sebaliknya jika ukuran kepiting bakau kecil maka proses pengerasan kulitnya relatif lebih cepat. Sedangkan kondisi lingkungan dipengaruhi oleh kualitas air dan substrat. Substrat tempat pemeliharaan akan mempengaruhi proses molting (ganti kulit) dan proses pengerasan. Substrat lumpur akan mempercepat proses pengerasan kerapas dan orgon tubuh lainnya pada tubuh kepiting. Hal ini sesuai habitat kepiting bakau dimana menurut Ariola bahwa selain di tepi sungai, kepiting bakau mempunyai habitat di sekitar muara sengai atau di tambak (Sukarya, 1991). Di dalam tambak periode molting ini sangat dipengaruhi oleh ukuran kepiting bakau yang dipelihara (Chong, 199). Perairan yang mempunyai substrat lumpur sangat sangat disenangi oleh kepiting bakau terutama untuk pelindungan saat pergantian kulit (Safiah, 1993). Diketahiu pula bahwa periode molting kepiting bakau sangat dipengaruhi oleh faktor internal seperti kesehatan dan proses pematangan gonad dan faktor eksternal yaitu ketersediaan pakan, temperatur dan salinitas.

\section{Kesimpulan}

Pemberian berupa pakan usus ayam pada kepiting bakau jenis kelamin jantan dan betina memberikan pertumbuhan mutlak (h) dan pertumbuhan harian (SGR) tertinggi. Tingkat kelangsungan hidup (SR) terbesar diperoleh dari pemberian pakan usus ayam. Periode molting tercepat berlangsung 14 hari pada pemberian pakan usus ayam dan terjadi pada jenis kelamin jantan.

\section{Daftar Pustaka}

Akbar, W., Yusnaini, \& H.M Wellem. (2016). The growth of mud crab (Scylla serrata) Fed Boiled Chicken Intestine and Trash Fish. Media Akuatika, 1(3), 190-196.

Cruz-Suarez, L. E., Nieto-López, M. G., Guajardo, C., Tapia-Salazar, M., Scholz, U., \& Ricque-Marie, D. (2007). Replacement of fish meal with poultry byproduct meal in practical diets for Litopenaeus vannamei, and digestibility of the tested ingredients and diets. Aquaculture, 272(1-4), 466-476.

Muchlisin, Z. ., Rudi, E., Muhammad, \& Setiawan, I. (2006). Pengaruh Perbedaan Jenis Pakan dan Ransum Harian Terhadap Pertumbuhan dan Kelangsungan Hidup Kepiting Bakau (Scylla serrata). ILMU KELAUTAN, 11(4), 227 - 233.

Safiah. (1993). Pengaruh Substrat Terhadap Pertumbuhan Kepiting Bakau Scylla serrata (Forskal). Universitas Dayanu Ikhsanuddin.

Sara, L., Muskita, W. H., \& Astuti, O. (2017). Some population parameters of blue swimming crab (Portunus pelagicus) in Southeast Sulawesi waters, Indon esia. Aquaculture, Aquarium, Conservation \& Legislation, 10(3), 587-601.

Sukarya, I. (1991). Pengaruh Salinitas Terhadap Kelangsungan dan Pertumbuhan Kepiting Bakau, Scylla serrata (Forskal). Institut Pertanian Bogor.

Tulangow, C., Santoso, P., \& Lukas, A. Y. H. (2019). Effect of feeding frequency of trash fish on growth of mangrove crab (Scylla serrata) Used battery system. Fakultas Kelautan dan Perikanan, Universitas Nusa Cendana. 50-61p). Aquatik, 2(2), 50-61.

Wahidin, A., Yusnaini, \& H.M Wellem. (2016). Pertumbuhan Kepiting Bakau (Scylla Serrata) yang Diberi Pakan Usus Ayam yang Dikukus dan Ikan Rucah. Media Akuatika, 1(3). 